\title{
ДЕРМАТОЛОГИЯ. АЛЛЕРГОЛОГИЯ
}

DOI: 10.22363/2313-0245-2018-22-3-288-301

\section{ALLERGEN IMMUNOTHERAPY: EFFICACY, PERSISTENCE, CONSISTENCY, AND COST EFFECTIVENESS}

\author{
Dana Wallace \\ Nova Southeastern University School of Medicine, Fort Lauderdale, Florida, USA
}

\begin{abstract}
Although allergen immunotherapy (AIT) has been used for the treatment of allergic rhinitis (AR), allergic conjunctivitis, asthma, stinging insect hypersensitivity, and atopic dermatitis for over 100 years, it has been slow to gain universal acceptance. With the publication of the "World Health Organization Position Paper, Allergen Immunotherapy" in 1998 which summarized the scientific evidence for the efficacy and long-term benefit of this therapy, it has become an accepted and respected modality of treatment. In this review there are discussed following topics of allergen immunotherapy: the reasons for recommending AIT, mechanism of action, subcutaneous and sublingual methods of application, duration, adherence and cost effectiveness. It is necessary to support, not blame, the patient for nonadherence as it is the responsibility of the patient, the physician, and the health-care system to create an environment in which the patient can be adherent. Nonadherence is multifactorial in most every patient and the physician must address all of the factors if adherence is to be improved. The greatest challenge is taking the time to create an individualized patient-tailored strategy to improve adherence, as one size does not fit all. Adherence is dynamic and selecting the best time to start AIT and assuring that there is close follow-up through AIT years of treatment is essential. The patient who is persistent and consistent in year one of AIT may not continue to be so in year three without added encouragement and support. The health-care systems and professional organizations need to help train physicians and their staff both in efficient and accurate ways to assess nonadherence and in implementing interventions to optimize adherence. The multidisciplinary approach to treating this disease of nonadherence will require the involvement of all healthcare professionals, researchers, professional organizations, insurance companies, and policy-makers.
\end{abstract}

Key words: allergen immunotherapy, subcutaneous, sublingual, adherence, cost effectiveness

Correspondence Author:

Dana Wallace, Associate Professor, Nova Southeastern Allopathic Medical School, Fort Lauderdale, Florida, Hollywood, FL 33019, USA. E-mail: drdanawallace@gmail.com

Для цитирования: Уоллес Д. Аллерген-специфическая иммунотерапия: эффективность, продолжительность, методы и фармакоэкономика // Вестник Российского университета дружбы народов. Серия: Медицина. 2018. Т. 22 . № 3. C. 288 -301. DOI: $10.22363 / 2313-0245-2018-22-3-288-301$.

For citation: D. Wallace. (2018). Allergen Immunotherapy: Efficacy, Persistence, Consistency and Cost Effectiveness. RUDN Journal of Medicine, 22 (3), 288-301. DOI: 10.22363/2313-0245-2018-22-3-288-301.

\section{INTRODUCTION}

Although allergen immunotherapy (AIT) has been used for the treatment of allergic rhinitis (AR), allergic conjunctivitis, asthma, stinging insect hypersensitivity, and atopic dermatitis for over 100 years, it has been slow to gain universal acceptance. With the publication of the "World Health Organization Position Paper, Allergen Immunotherapy" in 1998 which summarized the scientific evidence for the efficacy and long-term benefit of this therapy, it has become an accepted and respected modality of treatment [1]. 


\section{WHEN AND WHY TO INITIATE AIT}

AIT is only indicated in the US for the treatment of allergic rhinitis (AR) with or without allergic conjunctivitis, although many patients will also have coexisting asthma [2-4]. However, patients with uncontrolled asthma, should not be started on AIT. There should be a history of symptoms upon exposure to the aeroallergen for which there is evidence of allergen-specific sensitization as manifest by a positive skin test or serum-specific $\operatorname{IgE}[3]$. The presence of a positive aeroallergen skin test and nasal symptoms that do not correlate with the specific aeroallergen exposure is not adequate to recommend starting AIT. The most frequent reasons for recommending AIT is for patients who have moderate to severe AR, often manifest as having difficulty with daily activities and sleep, and who remain symptomatic despite maximum allergen avoidance and pharmacotherapy, experience adverse effects from pharmacotherapy, or choose to avoid long-term pharmacotherapy [5, 6]. Subcutaneous and sublingual immunotherapy provide AR symptom reduction, reduced pharmacotherapy, and may prevent the development of asthma and new allergen sensitizations [5, 7-11]. Multiple systematic reviews and meta-analyses, along with immunotherapy guidelines have concluded that there is insufficient data to determine the difference in efficacy for SCIT vs. SLIT for reduction of symptom and medication use for either AR or asthma [5, 8, 12-16]. It is recognized that AIT is the only treatment modality capable of bringing about immunological changes that can modify the underlying allergic disease. Following an adequate course of treatment, with three years usually considered the minimum, AIT has the potential to alter the natural history of disease with significant AR symptom reduction for up to 12 years following discontinuation of AIT $[5,17]$ and to prevent the development of asthma for up to 2 years post-AIT [15]. The strongest evidence for this effect comes from grass and birch AIT, with weak evidence for dust mite and other allergens [11]. Furthermore, a recent meta-analysis did not find evidence that AIT could provide long-term prevention [as opposed to short-term prevention] of developing asthma or new allergen sensitization $[11,15]$. AIT has not, to date, been shown to reduce the risk of developing a first allergic disease [15].

\section{ALLERGEN IMMUNOTHERAPY-MECHANISM OF ACTION}

AIT results in a very early reduction in the susceptibility of mast cells and basophils to degranulate even when exposed increased sIgE levels, in much the same way as desensitization to penicillin allergy works. There is also the development of allergenspecific immune tolerance and suppression of allergic inflammation. These early effects can be noted within hours [18]. The exact mechanisms that explain these changes are still being studied. AIT results in an increased $\mathrm{TH} 1 / \mathrm{Th} 2$ ratio. T-cell tolerance develops with a reduction of IL-4 secreting Th2 cells and an increase in IL-10 secreting T-reg cells, with a shift to a functional state similar to that of a non-allergic individual. The secretion of IL-10 and TGF- $\beta$, cytotoxic T lymphocyte antigen 4 and programmed death 1 protein on $\mathrm{T}$ cell surfaces play a major role in the suppressor effect of T-regs [18]. Allergen-specific B-regs are induced, while there is a reduction of allergen-specific IgE, an increase in allergen-specific IgG4 (blocking antibodies], and establishment of immune tolerance. AIT targets not only TH 2 cells (adaptive immunity) but type 2 innate lymphoid cells (innate immunity) and type 2 cytotoxic cells, resulting in reduced production of IL-4, IL-5, and IL-13 [18].

\section{SUBCUTANEOUS ALLERGEN IMMUNOTHERAPY}

The most robust research for the efficacy of SCIT derives from studies of seasonal allergic rhinitis (SAR), with fewer studies and more heterogenous results with the studies of perennial allergic rhinitis [16]. While SCIT for SAR has been successfully use both pre- and co-seasonally and year-round for pollen allergies, in the United States, it is usually administered year-round along with other perennial allergens. When directly comparing Pre- and co- 
seasonal SCIT with continuous SCIT for grass allergens, year-round SCIT may be more effective [19].

Most US allergists treat with a mixture of seasonal and perennial allergens, average of 8 allergens per treatment set $[20,21]$. There have been few wellcontrolled studies that have looked at the efficacy of allergen mixtures either for SCIT or SLIT. Using mixtures of grass pollen or mixtures of tree pollen for SCIT been shown to be effective [19]. One SCIT study using mixed grass/birch pollen demonstrated efficacy [22]. A SLIT study using a mixture of dust mite and rye grass in children reported efficacy [23]. However, a SLIT drop study showed that there was reduced efficacy when mixing a grass pollen in a 9pollen extract vs. administering the equivalent dose of grass as an individual SLIT extract [24]. The European Medications Agency, the equivalent of our FDA, has recommended that only homologous antigens be mixed [16] . The 2011 JTFPP Allergen Immunotherapy Practice Parameter reported on 3 studies using multiple [more than 2] allergens that showed efficacy [25-27] and 2 studies that did not demonstrate efficacy for multiple allergen SCIT, recommending that further research was needed [28, 29].

In the US, SCIT is administered almost exclusively in aqueous form, while in Europe it is usually used as a depot absorbed on aluminum hydroxide or tyrosine. Both forms of SCIT have been shown to be effective; however, in meta-analysis the aqueous form showed a slightly higher standardized mean difference (SMD) compared to placebo [3]. But, there have not been any head-to-head randomized DBPC trials comparing these two forms of treatment [16].

\section{SUBLINGUAL ALLERGEN IMMUNOTHERAPY (SLIT)}

Although available since the 1990's in Europe, SLIT was first approved by the FDA for use in the US in 2014. SLIT tablets are now available in the US for northern grasses, ragweed, and dust mite. SLIT for pollen allergies can be used pre- and co-seasonally, ideally starting 4 months prior to season, or year- round. Both SLIT tablets and drops are approved for use in Europe but only SLIT tablets are approved in the US. While allergists and ENT physicians in the US are using SLIT drops made from aqueous extract (which has been FDA approved for SCIT) in an offlabel manner, the efficacy of such treatment has not been established. Most US SLIT aqueous drops contain multiple allergens, which has yet to be proven to be effective. Administering these aqueous drops to include antigen doses equivalent to that found in SLIT tablets is both impractical (volume too great) and cost prohibitive. Furthermore, this treatment is not covered by third-party payers.

In Europe, where both SLIT tablets and drops are approved products, the superior efficacy of tablets is supported by higher quality research for shortterm reduction of symptoms and rescue medications for SAR while only SLIT tablets have been shown to have convincing efficacy for perennial AR [16]. When deciding between pre/co-seasonal or yearround treatment, the only studies showing persistent benefit for 2 years following three years of grass pollen SLIT tablets, used year-round treatment [30, 31 ]. However, even in this study, the $40 \%$ improvement in symptoms reported at the end of the three years of active treatment had declined to $20 \%$ by the end of the $2^{\text {nd }}$ year off treatment, losing statistical significance [31]. The two grass SLIT tablets available in the US have both been approved for pre- and co-seasonal use. One product is also approved for year-round treatment and has data that year-round treatment can provide at least one year of symptom reduction following discontinuation of 3 years of treatment. Therefore, most clinicians will likely recommend year-round pollen treatment for most patients.

Most of the high-quality SLIT research has been with pollen allergens. For dust mite SLIT, the EAACI guidelines recommend at least one year of SLIT for short term symptom reduction of AR in adults [16]. However, lower quality research suggests that at least 4 years of treatment is needed for best results $[31,32]$. 


\section{DURATION OF AIT}

Questions still remain regarding recommended duration of AIT for both season and perennial allergens. For year-round SCIT, 3 years is generally accepted as the minimum [32], but the ideal duration of AIT for long-term benefit has not been determined, although longer e.g., $4-5$ years vs. 3 years, has been reported to be superior in some but not all studies [33-35]. Comparing 3, 4 and 5 years of SLIT dust mite year-round treatment in a controlled but non-randomized study, long-term symptoms improvement for 7,8, and 8 years, respectively, after discontinuing SLIT was demonstrated $[31,32]$. The researchers, therefore, suggested that 4 years may be the ideal length of SLIT dust-mite treatment [31, 32]. Similar data for other perennial allergens have not been published.

\section{ADHERENCE TO AIT}

However, only a small proportion of appropriately selected candidates for AIT elect to initiate treatment. Of those who start AIT, a high percentage are non-adherent to the recommended treatment schedule, often discontinuing therapy before completion of the recommended 3 to 5 years needed to achieve sustained clinical benefit [36-38]. It is estimated that of the 24 million adults in the US with AR, 10 million are candidates for AIT, but only 3.5 million initiate AIT and up between $11 \%$ to $97 \%$ discontinue therapy before reaching 3 years of therapy [39-47].

\section{DEFINITION AND PREVALENCE OF NON-ADHERENCE}

Adherence and compliance are often used interchangeably, however, compliance implies following or yielding to the proposed treatment plan that has been prescribed by the physician. Adherence differs from compliance as adherence requires the patient's agreement to the recommendation; patients should be active, informed, participants in the decision, e.g., to start allergen immunotherapy [48]. The World Health Organization (WHO) defines adherence as ... the extent to which a person's behavior - taking medication (including AIT), following a diet, and or executing lifestyle changes-corresponds with the agreed recommendations of a provider [49]. When the physician and patient have participated in shared decision-making, there is better patient engagement, the building of a stronger physician-patient trust, and usually better outcomes [50]. While the expectation is that shared-decision making improves adherence, it has proven to be only one component of a complex intervention strategy which involves many additional elements, e.g., incorporating structured education, often using a variety of patient decision aids, teaching self-management skills, and using a frequent and consistent reminder system [51]. The World Health Organization has reported that only about $50 \%$ of patients with chronic illnesses take their medication as prescribed, even for diseases such as cardiovascular disease and diabetes mellitus when the mortality rate is known to be nearly double for non-adherence $[49,52]$. For children with asthma or adults with chronic obstructive pulmonary disease, long-term full adherence to prescribed medications does not exceed $25 \%[53,54]$. When looking broadly at adherence, it is felt that patients perceptions, beliefs, and attitudes toward taking the medication has more impact on their actions than age, cost, inconvenience, or adverse effects [55].

\section{ECONOMIC IMPACT OF MEDICATION NON-ADHERENCE}

The economic impact of medication non-adherence has been widely studied. It is estimated that in the US the annual cost for medication nonadherence ranges from $\$ 100$ to $\$ 290$ billion [56]. In a systematic review of 79 individual studies, the annual cost of "all causes" of non-adherence ranged from $\$ 5271$ to $\$ 52,341$ per person [57]. Unfortunately, the voluminous research assessing the economic impact of medication non-adherence has failed to affect healthcare policy, largely due, in Cutler's opinion, to the varying quality of the research and to the use of non-standardized methods of measuring adherence [57]. However, the impact of political and financial implications cannot be ignored. Non- 
adherence itself is often treated as a disease, perhaps explaining the fact that policy makers in the US do not allow increased premiums to be charged by insurance companies or employees for non-adherence [58].

\section{ALLERGEN IMMUNOTHERAPY ADHERENCE: PERSISTENCE AND CONSISTENCY}

What constitutes adherence or nonadherence has not really been uniformly or operationally defined for most medical treatments and certainly not for AIT, either in research or in real life. To avoid confusion of these closely related terms, the term "adherence" will incorporate both "persistence" of AIT and "consistency" of AIT. "Persistence" will refer to the degree to which the patient adheres to a three-year minimum course of AIT. "Consistency" will refer to the degree to which all scheduled allergy injections or SLIT tablets or drops are taken, as prescribed.

\section{LITERATURE REVIEW OF PERSISTENCE OF AIT}

The most relevant studies to determine adherence to AIT in clinical practice are derived from "real-life" studies and not controlled studies. The most meaningful studies are those that compare SCIT and SLIT head-to-head in the same research protocol. Nine studies, comparing persistence of SCIT to that of SLIT for a minimum of three years, published 2001-2018 were reviewed [39-47]. A total of 105,302 patients were included in these 9 studies [SCIT:96,297; SLIT8913:8913: Local nasal immunotherapy (LNIT), 82]. For SCIT, the discontinuation rate varied from $11 \%$ to $95 \%$ and for SLIT from $22 \%$ to $97 \%$. Not factoring in study size, the mean discontinuation rate was $54 \%$ for SCIT and $58 \%$ for SLIT for these 9 studies. However, perhaps the most accurate SLIT discontinuation rates derive from the sales data of 2 major SLIT manufacturers, accounting for approximately $60 \%$ of the Italian SLIT marketplace from 2006-2009 [59]. That study reports an $87 \%$ discontinuation over these three years [59]. In a US clinical setting without any elements of an observational study, the best data for SCIT persistence, with a $12 \%$ discontinuation rate, was from a region with an homogenous population, served by a large multi-specialty medical clinic [60].

The reasons for discontinuation in many of the studies reviewed were not defined, often due to the study design, e.g., pharmacy databases, for 6 of 16 studies reviewed. When this information was reported, it was usually based upon a sampling, usually $<50 \%$ of the total patients studied. In three studies, the chart did not indicate the reason or over $50 \%$ of the patients studied were unwilling to state a reason for discontinuation of AIT. Based upon limited reporting, reasons given for discontinuation of SCIT (in overall descending order) included: 1) inconvenience and excessive time commitment; 2) medical comorbidities, especially psychiatric and pregnancy; 3) financial concerns; 4) relocation of residence; 5) symptom improvement; 6) family problems; and 7) adverse effects. Lack of efficacy was rarely mentioned. For SLIT, the reasons for discontinuation, (in overall descending order) were: 1) lack of efficacy; 2) adverse effects; 3 ) inability to be compliant; 4) financial concerns; 5) symptoms reduction; 6) excessive time commitment; and 7) family problems. Most of the US persistence studies were completed before 2011 with only one completed in 2014. Due to the changes in healthcare delivery over the past 7 years in the US, it is likely that patients' direct financial burden for AIT is playing a much larger role in both failing to initiate AIT and in discontinuation of AIT.

Looking at demographic patterns for nonpersistence of AIT, children, especially those 514 years of age, were the most persistent age group both for SCIT and SLIT. Adolescents and young adults had a high discontinuation rate, while adults over 40 were more persistent. Sex, socioeconomic status, and type of payment for AIT did not seem, overall, to be major factors in predicting discontinuation of AIT. Most non-persistence for both SCIT and SLIT occurs during the first year of treatment, 
especially during the first 3 months. However, SLIT patients tended to discontinue AIT sooner than did SCIT patients. If patients continued into the $2^{\text {nd }}$ year of AIT, they were more likely to complete the third year. Patients prescribed AIT and treated by allergists vs. non-allergists had lower discontinuation rates. Patients with more allergies vs. those with only a few allergies were more likely to initiate AIT and often selected SLIT over SCIT. Patients with asthma were more likely to select SLIT compared to SCIT. Patients were less likely to initiate and more likely to discontinue AIT if they had multiple medical comorbidities. Failure to initiate AIT that had been recommended, as reported by patients in an internet survey, was due to financial concerns $(34 \%)$, practical constraints (31\%), insufficient perceived benefit (25\%), and fear of adverse events (22\%) [48].

Consistency was defined as the percentage of the prescribed doses of SCIT that were actually received as injections or doses of SLIT taken as drops/tablets. In countries where SLIT and SCIT are dispensed as pharmacy products, the refill records were used to determine consistency. Some studies only reported consistency for the patients who had also been persistent with their AIT. Unfortunately, only 3 of the 9 studies comparing SCIT and SLIT reviewed for persistence also reported on consistency [40, 43, 44], and these 3 studies all used different methods to determine consistency. Based upon a large German health disease database, of those who were persistent for 3 years, there was $83 \%$ and $81 \%$ consistency for SIT and SLIT, respectively, based upon the \% of days for which prescribed doses were in the possession of the patients [40]. A Netherlands community pharmacy database study defined consistency as not being late for refilling any of the SLIT and SCIT treatment sets [43]. In this study, all non-persistent patients were considered non-consistent. Of the persistent patients $(23 \%$ of all SCIT patients and 7\% of all SLIT patients) who were treated with only one allergen (75\% and $63 \%$ of patients of SCIT and SLIT, respectively), 56\% were also consistent [no late pharmacy visits] and
$44 \%$ had a mean of 1.4 late pharmacy visits [43]. The persistent SLIT group had an odds ratio of 2.8 of being late compared to the persistent SCIT group. Overall, $38 \%$ and $62 \%$ of the SCIT and SLIT group, respectively, as defined above, were non-consistent, meaning that they were late for picking up their treatment sets [43]. A US Otolaryngology (ENT) university clinic categorized consistency as excellent, good, fair, or poor based upon the number of 2-week breaks in scheduled treatments per year [44]. They found that consistency for SCIT patients was excellent or good, $62 \%$ and $22 \%$ of the time, respectively. For SLIT patients, the consistency was excellent or good $31 \%$ and $35 \%$ of the time, respectively [44].

\section{TYPES OF NONADHERENCE}

Clinicians must recognize that nonadherence comes in many different forms that can be categorized, in general, as 1) erratic nonadherence, 2) unwitting nonadherence, and 3) intelligent nonadherence [49]. While often described for the management of other chronic diseases, e.g., asthma, they also can be applied to AIT.

The erratic nonadherence is likely to be the most common, easily identified by patients and physicians, and is often due to forgetfulness and complex and/or chaotic life styles. Patients understand the reasons for adherence and ideally want to be adherent but have not prioritized AIT within their busy schedules. Simplified and convenient treatment regimens, behavior modification, and reminder aids may be offered.

Unwitting nonadherence is described when patients fail to fully understand the specifics or the necessity of the recommended treatment regimen. With AIT, patients are often unaware or forget that consistency and persistence with AIT are required for immunological changes that can provide longterm benefit after cessation of treatment; adherence is required even when current symptoms are under excellent control. Each office visit, including AIT injections, is an opportunity for on-going education and discussion of the long-term benefits of AIT. 
Intelligent nonadherence is seen when the patient completes allergy testing but fails to initiate treatment after having agreed to do so. Additionally, patients may alter the treatment regimen or even discontinue therapy, deliberately, and for personal reasons. Patients may reach this decision as they start to feel better and no longer feel the need to take the treatment, dislike or fear short or long-term side effects of AIT, are encouraged by family members to stop, cannot afford the treatment, are unwilling to devote the time required, or prefer to use pharmacotherapy. The patient has already made, at least informally, a risk-benefit assessment. Many of these patients may be reluctant to provide the reason that they stopped AIT, if asked. To address this type of nonadherence, the physician must spend time with the patient engaging in an open-ended, non-judgmental conversation, attempt to provide alternative solutions to the patient's individual barriers and concerns, and be prepared to accept the patient's final decision of continuation or discontinuation of AIT.

\section{RESEARCH STUDIES ON IMPROVING AIT ADHERENCE: KEY FINDINGS}

- The first 3-12 months, when most nonpersistence occurs with both SLIT and SCIT, are crucial for patient education, patient engagement, and follow-up [43, 45, 48, 61, 62].

- Directly questioning the patient about adherence is of little value as patients overestimate their degree of consistency.

- A multi-faceted approach of education, frequent contacts (phone, text) and strictly scheduled office visits totally at least 5 contacts, and $1 \frac{1}{2}$ hours of professional/personnel time over the first year of SLIT, reduced the discontinuation rate from $35 \%$ (control group) to $12 \%$ (intervention group) [63].

- SLIT local side effects result in a high discontinuation rate at 10 days thru 4 months. Frequent phone calls, office visits, and reeducation can re-enroll patients who have stopped their treatment [63].

- Follow-up visits during the first year of AIT should be a minimum of $4 \mathrm{x} / \mathrm{year}$ which can decrease the discontinuation rate from $29 \%$ to $8 \%$ over the first year [64].

- Using a minimum of dose reductions, e.g., seasonal peak or missed appointment, can improve adherence without an increase in adverse events $[65,66]$.

- Using alternative SCIT build-up schedules, e.g., RUSH or cluster, may improve adherence in some but not all patients [67-71].

- Avoidance of all beta-blockers and ACE inhibitor/receptor blockers is a relative but not absolute contraindication for AIT [72, 73].

- Try alternative dosing schedules in children to prevent local and mild systemic reactions $[74,75]$.

- For SLIT local reactions, consider pretreatment with antihistamines, split tablet administration, moving tablet to other parts of vestibulum, and avoiding swallowing of the tablet $[16,61]$.

- Consider night-time dosing for SLIT based on consistency with asthma medications being better in the evening [76].

- Engage your local pharmacists in patient education and adherence. Allergists and pharmacists should ideally develop and actively participate in a personalized adherence plan for every patient on SLIT [77, 78].

- Consider engaging patient ambassadors for patient support groups.

- When patients admit to being non-adherent, this is usually truly the case, although even then they overestimate their degree of adherence by $17 \%$ [79]. When they report being adherent, this is true about $50 \%$ of the time [79].

- Developing a clinical impression of adherence based upon the patient's socioeconomic status, educational level, perceived motivation, and other patient characteristics is perhaps the most inaccurate assessment of adherence [80].

- Assuming that a patient who remains symptomatic is non-adherent can be detrimental for the clinician-patient relationship and also may prevent a modification of treatment course that can benefit the patient. Thus, health outcomes can never serve 
as a proxy for a measurement of adherence [81]. Furthermore, this method offers no insight into patterns of behavior that contribute to nonadherence.

- Become proficient in conducting a shareddecision making discussion with the patient and extended family [82]. Use the ACAAI's on-line educational tool that reinforces AIT shared-decision making [83].

- Use motivational interviewing (MI) incorporating the four key components of MI, 1) open-ended questions, 2) affirmations, 3) reflective listening, and 4) summary statements, as this has been shown to increase patient satisfaction and treatment adherence [84].

- Use more objective measures for measuring adherence and disease control such as the RCAT, $\mathrm{ACT}$, and the "Allergen Immunotherapy Adherence Questionnaire", based upon a modification of the Morisky MMAS-8.

- There are some barriers to AIT adherence in real-life and improvement strategies.

\section{COST EFFECTIVENESS}

There have been many studies exploring the pharmacoeconomics of both subcutaneous [SCIT] and sublingual (SLIT) in allergic disease, including several recent reviews, but interestingly, very few studies have been performed in the United States [85-88]. These studies almost universally demonstrate that there are cost savings of IT, with time to achieve this goal varying from 3 months to several years.

A series of studies examined resource utilization and costs of SCIT through examination of a Medicaid population. The first relied upon a retrospective analysis of Florida Medicaid claims data (19972004) analysis in children given a new diagnosis of AR, finding significantly reduced resource use, e.g., pharmacy claims, outpatient visits, and inpatient resources and resultant reduced costs comparing 6 months before versus 6 months after AIT [62]. Using the same database and reviewing claims 1997-2007 for children with newly diagnosed asthma, The authors found that those children treated with SCIT had significantly lower 18-month median per-patient total health care costs $(\$ 3,247$ vs $\$ 4,872)$, outpatient costs exclusive of immunotherapy-related care $(\$ 1,107$ vs $\$ 2,626)$, and pharmacy costs $(\$ 1,108$ vs $\$ 1,316)$ compared with matched controls $(\mathrm{P}<$ $<0.001$ for all) [89]. Using a similar Florida Medicaid claims database, a retrospective analysis of both children and adults found that that the group that received SCIT had a $38 \%(\$ 6,637$ vs $\$ 10,644, \mathrm{P}<$ $<0.0001$ ) lower mean 18-month total health care cost compared to the matched control subjects, noting significant savings within 3 months of initiating SCIT [90].

A study using the Optum Research Database from January 2009 through February 2014 for adults and pediatric patients who remained on SCIT found reduced oral corticosteroid use, respiratory-related emergency visits, and in-hospitals stays but had a greater mean total AR-related cost than those who discontinued SCIT ( $\$ 1918$ vs. $\$ 646, p<0.001$ ) [91]. However, when using unadjusted mean total respiratory-related costs, there was an advantage to continuing AIT.

Studies outside the US have looked at both SCIT and SLIT studies. Reviewing some of the studies completed after 2005, we see 5 very wellconducted studies. A 2006 prospective, randomized, open-label, parallel-group Italian study compared SLIT for parietaria pollen to standard treatment (ST) [92]. The cost savings were statistically significant after 3 yrs. and showed $\$ 958$ of savings after 6 years. The same year a Dutch retrospective administrative claims analysis looked at dust mite and/or pollen 4-year treatment with SVIT vs. ST in 235 adults with $\mathrm{AR}+/-$ asthma [93]. There was cost a saving of $\$ 215,1$ year post-SCIT vs. 1 year pre-SCIT. However, for the entire 4 years of SCIT, there were no overall savings. A 2008 Czech Republic economic modeling study compared SCIT vs. SLIT vs. ST for allergic rhinoconjunctivitis in adults [94]. Medication costs were reduced after 2 years of AIT and the groups had $60 \%$ (SLIT) and (55\% SCIT) cost savings vs. XT after 3 years. 
Another 2008 economic modeling study in Germany compared 3 years of SCIT vs. ST overs 15 years, showing a 10 -year break-even point. At 15 years cost were less for SCIT $(\$ 16392)$ vs. ST $(\$ 17,826)$. The SCIT incremental cost-effectiveness ratio (ICER) was \$4077/Quality Adjusted Life Year (QALY) demonstrating cost-effectiveness. A SLIT grass tablet was shown to be cost-effective for Northern European countries, based on QALY, as long as SLIT costs were $\leq € 2200$ year [95].

Looking critically at all of the cost-effectiveness data, the 2017 EAACI AIT guidelines concluded that AIT was cost effectiveness after 6 years of treatment and reduced health-care expenditures from $12 \%$ to $80 \%$ [16]. Based upon 7 randomized controlled studies, using a calculated QALY, they found that SCIT and SLIT were cost-effective, based upon the National Institute for Health and Care excellence [NICE] cost effectiveness threshold of $€ 24,616$ per QALY. Taking all of the above information into consideration, it can be concluded that both SCIT and SLIT are cost-effective in both the US and outside the US but one is unable to say if one form of AIT is more cost-effective than another.

Several SLIT pharmacoeconomic studies have been published, but all outside the US, making comparisons with the US very difficult. One German study looked at SCIT vs. pharmacotherapy for the management of SAR and PAR, and created a model which incorporated a multifaceted assessment of AR with a ten-year follow-up, including the potential impact on asthma. They found that the break-even point was reached between 6 to 8 years after starting AIT, for a savings of $\$ 380-\$ 693 /$ patient after 10 years [96].

Overall, studies examining the pharmacoeconomics of allergy immunotherapy demonstrate a cost savings. Studies have varied regarding the breakeven point, with some as little as 3 months, while others have demonstrated a lag of $6-8$ years to see this achieved. One thing is for sure, the paucity of patients achieving the recommended 3-5 years of treatment duration, makes it unlikely that the cost effectiveness of AIT is maximized.

\section{CONCLUSION}

We need to support, not blame, the patient for nonadherence as it is the responsibility of the patient, the physician, and the health-care system to create an environment in which the patient can be adherent. Nonadherence is multifactorial in most every patient and the physician must address all of the factors if adherence is to be improved. Perhaps the greatest challenge is taking the time to create an individualized patient-tailored strategy to improve adherence, as one size does not fit all. Adherence is dynamic and selecting the best time to start AIT and assuring that there is close follow-up through AIT years of treatment is essential. The patient who is persistent and consistent in year one of AIT may not continue to be so in year three without added encouragement and support.

The health-care systems and professional organizations need to help train physicians and their staff both in efficient and accurate ways to assess nonadherence and in implementing interventions to optimize adherence. The multidisciplinary approach to treating this disease of nonadherence will require the involvement of all healthcare professionals, researchers, professional organizations, insurance companies, and policy-makers. If we can achieve good to excellent adherence to AIT, the cost-effective puzzle piece may fall into place. Ultimately, we as clinicians, need to respect the wishes of our patients and accept their decision on whether to start and to continue with AIT or to discontinue treatment, as long as it is a rational, informed decision based upon their personal experiences and values.

\section{REFERENCES / БИБЛИОГРАФИЧЕСКИЙ СПИСОК}

1. Bousquet J, Lockey R, Malling HJ, Alvarez-Cuesta E, Canonica GW, Chapman MD, et al. Allergen immunotherapy: therapeutic vaccines for allergic diseases. World Health Organization. American academy of Allergy, Asthma and Immunology. Ann Allergy Asthma Immunol. 1998;81[5]:401—5. 
2. Bousquet J, Khaltaev N, Cruz AA, Denburg J, Fokkens WJ, Togias A, et al. Allergic Rhinitis and its Impact on Asthma [ARIA] 2008 update [in collaboration with the World Health Organization, GA[2]LEN and AllerGen]. Allergy. 2008;63 Suppl 86:8-160.

3. Dhami S, Nurmatov U, Arasi S, Khan T, Asaria M, Zaman $\mathrm{H}$, et al. Allergen immunotherapy for allergic rhinoconjunctivitis: A systematic review and metaanalysis. Allergy. 2017;72[11]:1597—631.

4. Bousquet J, Lockey R, Malling HJ. Allergen immunotherapy: therapeutic vaccines for allergic diseases. A WHO position paper. J Allergy Clin Immunol. 1998; 102[4 Pt 1]:558 - 62.

5. Burks AW, Calderon MA, Casale T, Cox L, Demoly P, Jutel M, et al. Update on allergy immunotherapy: American Academy of Allergy, Asthma \& Immunology/European Academy of Allergy and Clinical Immunology/PRACTALL consensus report. $J$ Allergy Clin Immunol. 2013;131[5]:1288—96 e3.

6. Ponda P, Mithani S, Kopyltsova Y, Sison C, Gupta P, Larenas D, et al. Allergen immunotherapy practice patterns: a worldwide survey. Ann Allergy Asthma Immunol. 2012;108[6]:454—9 e7.

7. Kim JM, Lin SY, Suarez-Cuervo C, Chelladurai Y, Ramanathan M, Segal JB, et al. Allergen-specific immunotherapy for pediatric asthma and rhinoconjunctivitis: a systematic review. Pediatrics. 2013;131[6]:1155—67.

8. Lin SY, Erekosima N, Suarez-Cuervo C, Ramanathan M, Kim JM, Ward D, et al. AHRQ Comparative Effectiveness Reviews. Allergen-Specific Immunotherapy for the Treatment of Allergic Rhinoconjunctivitis and/or Asthma: Comparative Effectiveness Review. Rockville [MD]: Agency for Healthcare Research and Quality [US]; 2013.

9. Senna G, Ridolo E, Calderon M, Lombardi C, Canonica GW, Passalacqua G. Evidence of adherence to allergen-specific immunotherapy. Curr Opin Allergy Clin Immunol. 2009;9[6]:544-8.

10. Canonica GW, Bousquet J, Casale T, Lockey RF, BaenaCagnani CE, Pawankar R, et al. Sub-lingual immunotherapy: World Allergy Organization Position Paper 2009. Allergy. 2009;64 Supp1 91:1-59.

11. Halken S, Larenas-Linnemann D, Roberts G, Calderon MA, Angier E, Pfaar O, et al. EAACI guidelines on allergen immunotherapy: Prevention of allergy. Pediatr Allergy Immunol. 2017;28[8]:728 - 45.

12. Dhami S, Kakourou A, Asamoah F, Agache I, Lau S, Jutel $\mathrm{M}$, et al. Allergen immunotherapy for allergic asthma: A systematic review and meta-analysis. Allergy. 2017;72[12]:1825—48.
13. Nurmatov U, Dhami S, Arasi S, Roberts G, Pfaar O, Muraro A, et al. Allergen immunotherapy for allergic rhinoconjunctivitis: a systematic overview of systematic reviews. Clin Transl Allergy. 2017;7:24.

14. Meadows A, Kaambwa B, Novielli N, Huissoon A, FrySmith A, Meads C, et al. A systematic review and economic evaluation of subcutaneous and sublingual allergen immunotherapy in adults and children with seasonal allergic rhinitis. Health Technol Assess. 2013; 17[27]:vi, xi-xiv, 1-322.

15. Kristiansen M, Dhami S, Netuveli G, Halken S, Muraro A, Roberts G, et al. Allergen immunotherapy for the prevention of allergy: A systematic review and meta-analysis. Pediatr Allergy Immunol. 2017;28[1]:18 -29.

16. Roberts G, Pfaar O, Akdis CA, Ansotegui IJ, Durham SR, Gerth van Wijk R, et al. EAACI Guidelines on Allergen Immunotherapy: Allergic rhinoconjunctivitis. Allergy. 2018;73[4]:765-98.

17. Eng PA, Borer-Reinhold M, Heijnen IA, Gnehm HP. Twelve-year follow-up after discontinuation of preseasonal grass pollen immunotherapy in childhood. Allergy. 2006;61[2]:198-201.

18. Jutel M, Agache I, Bonini S, Burks AW, Calderon M, Canonica W, et al. International Consensus on Allergen Immunotherapy II: Mechanisms, standardization, and pharmacoeconomics. J Allergy Clin Immunol. 2016; 137[2]:358-68.

19. Tworek D, Bochenska-Marciniak M, Kuprys-Lipinska I, Kupczyk M, Kuna P. Perennial is more effective than preseasonal subcutaneous immunotherapy in the treatment of seasonal allergic rhinoconjunctivitis. Am J Rhinol Allergy. 2013;27[4]:304-8.

20. Esch RE. Specific immunotherapy in the U.S.A.: general concept and recent initiatives. Arb Paul Ehrlich Inst Bundesamt Sera Impfstoffe Frankf A M. 2003[94]:17-22; discussion 3.

21. Cox L, Jacobsen L. Comparison of allergen immunotherapy practice patterns in the United States and Europe. Ann Allergy Asthma Immunol. 2009;103[6]:451—59; quiz 9-61, 95.

22. Pfaar O, Biedermann T, Klimek L, Sager A, Robinson DS. Depigmented-polymerized mixed grass/birch pollen extract immunotherapy is effective in polysensitized patients. Allergy. 2013;68[10]:1306-13.

23. Swamy RS, Reshamwala N, Hunter T, Vissamsetti S, Santos CB, Baroody FM, et al. Epigenetic modifications and improved regulatory $\mathrm{T}$-cell function in subjects undergoing dual sublingual immunotherapy. J Allergy Clin Immunol. 2012;130[1]:215-24 e7. 
24. Amar SM, Harbeck RJ, Sills M, Silveira LJ, O'Brien H, Nelson HS. Response to sublingual immunotherapy with grass pollen extract: monotherapy versus combination in a multiallergen extract. $J$ Allergy Clin Immunol. 2009; 124[1]:150-6 e $1-5$.

25. Lowell FC, Franklin W. A double-blind study of the effectiveness and specificity of injecton therapy in ragweed hay fever. $N$ Engl J Med. 1965;273[13]:675—9.

26. Franklin W, Lowell FC. Comparison of two dosages of ragweed extract in the treatment of pollenosis. JAMA. 1967;201[12]:915-7.

27. Johnstone DE, Dutton A. The value of hyposensitization therapy for bronchial asthma in children - a 14-year study. Pediatrics. 1968;42[5]:793 - 802.

28. Bousquet J, Becker WM, Hejjaoui A, Chanal I, Lebel B, Dhivert H, et al. Differences in clinical and immunologic reactivity of patients allergic to grass pollens and to multiple-pollen species. II. Efficacy of a double-blind, placebo-controlled, specific immunotherapy with standardized extracts. J Allergy Clin Immunol. 1991;88[1]:43-53.

29. Adkinson NF, Jr., Eggleston PA, Eney D, Goldstein EO, Schuberth KC, Bacon JR, et al. A controlled trial of immunotherapy for asthma in allergic children. $N \mathrm{Engl}$ J Med. 1997;336[5]:324-31.

30. Durham SR, investigators GT. Sustained effects of grass pollen AIT. Allergy. 2011;66 Suppl 95:50-2.

31. Durham SR, Emminger W, Kapp A, de Monchy JG, Rak S, Scadding GK, et al. SQ-standardized sublingual grass immunotherapy: confirmation of disease modification 2 years after 3 years of treatment in a randomized trial. J Allergy Clin Immunol. 2012;129[3]:717-25 e5.

32. Marogna M, Spadolini I, Massolo A, Canonica GW, Passalacqua G. Long-lasting effects of sublingual immunotherapy according to its duration: a 15-year prospective study. J Allergy Clin Immunol. 2010;126[5]:969-75.

33. Frati F, Dell'Albani I, Incorvaia C. Long-term efficacy of allergen immunotherapy: what do we expect? Immunotherapy. 2013;5[2]:131-3.

34. Durham SR, Walker SM, Varga EM, Jacobson MR, O'Brien F, Noble W, et al. Long-term clinical efficacy of grass-pollen immunotherapy. $N$ Engl J Med. 1999; 341[7]:468-75.

35. Des Roches A, Paradis L, Knani J, Hejjaoui A, Dhivert H, Chanez P, et al. Immunotherapy with a standardized Dermatophagoides pteronyssinus extract. V. Duration of the efficacy of immunotherapy after its cessation. Allergy. 1996;51[6]:430-3.

36. Incorvaia $\mathrm{C}$, Riario-Sforza GG, Incorvaia S, Frati F. Sublingual immunotherapy in allergic asthma: Current evidence and needs to meet. Ann Thorac Med. 2010; $5[3]: 128-32$.
37. Cox L, Cohn JR. Duration of allergen immunotherapy in respiratory allergy: when is enough, enough? Ann Allergy Asthma Immunol. 2007;98[5]:416-26.

38. Brehler R, Klimek L, Kopp MV, Christian Virchow J. Specific immunotherapy-indications and mode of action. Dtsch Arztebl Int. 2013;110[9]:148—58.

39. Anolik R, Schwartz AM, Sajjan S, Allen-Ramey F. Patient initiation and persistence with allergen immunotherapy. Ann Allergy Asthma Immunol. 2014;113[1]: $101-7$.

40. Allam JP, Andreasen JN, Mette J, Serup-Hansen N, Wustenberg EG. Comparison of allergy immunotherapy medication persistence with a sublingual immunotherapy tablet versus subcutaneous immunotherapy in Germany. J Allergy Clin Immunol. 2018;141[5]:1898-901 e5.

41. Egert-Schmidt AM, Kolbe JM, Mussler S, Thum-Oltmer S. Patients' compliance with different administration routes for allergen immunotherapy in Germany. Patient Prefer Adherence. 2014;8:1475-81.

42. Hsu NM, Reisacher WR. A comparison of attrition rates in patients undergoing sublingual immunotherapy vs subcutaneous immunotherapy. Int Forum Allergy Rhinol. 2012;2[4]:280-4.

43. Kiel MA, Roder E, Gerth van Wijk R, Al MJ, Hop WC, Rutten-van Molken MP. Real-life compliance and persistence among users of subcutaneous and sublingual allergen immunotherapy. J Allergy Clin Immunol. 2013; 132[2]:353-60 e2.

44. Leader BA, Rotella M, Stillman L, DelGaudio JM, Patel ZM, Wise SK. Immunotherapy compliance: comparison of subcutaneous versus sublingual immunotherapy. Int Forum Allergy Rhinol. 2016;6[5]:460 - 4.

45. Lemberg ML, Berk T, Shah-Hosseini K, Kasche EM, Mosges R. Sublingual versus subcutaneous immunotherapy: patient adherence at a large German allergy center. Patient Prefer Adherence. 2017;11:63-70.

46. Pajno GB, Vita D, Caminiti L, Arrigo T, Lombardo F, Incorvaia $\mathrm{C}$, et al. Children's compliance with allergen immunotherapy according to administration routes. $J$ Allergy Clin Immunol. 2005;116[6]:1380-1.

47. Sieber J, De Geest S, Shah-Hosseini K, Mosges R. Medication persistence with long-term, specific grass pollen immunotherapy measured by prescription renewal rates. Curr Med Res Opin. 2011;27[4]:855-61.

48. Calderon MA, Cox L, Casale TB, Mosges R, Pfaar O, Malling HJ, et al. The effect of a new communication template on anticipated willingness to initiate or resume allergen immunotherapy: an internet-based patient survey. Allergy Asthma Clin Immunol. 2015;11[1]:17.

49. Sabate E. Adherence to Long-Term Therapies: Evidence for Action. Geneva, Switzerland; 2003. 
50. Denford S, Frost J, Dieppe P, Cooper C, Britten N. Individualisation of drug treatments for patients with long-term conditions: a review of concepts. BMJ Open. 2014;4[3]:e004172.

51. Costa E, Giardini A, Savin M, Menditto E, Lehane E, Laosa $\mathrm{O}$, et al. Interventional tools to improve medication adherence: review of literature. Patient Prefer Adherence. 2015;9:1303-14.

52. Ho PM, Magid DJ, Masoudi FA, McClure DL, Rumsfeld JS. Adherence to cardioprotective medications and mortality among patients with diabetes and ischemic heart disease. BMC Cardiovasc Disord. 2006;6:48.

53. Krishnan JA, Bender BG, Wamboldt FS, Szefler SJ, Adkinson NF, Jr., Zeiger RS, et al. Adherence to inhaled corticosteroids: an ancillary study of the Childhood Asthma Management Program clinical trial. J Allergy Clin Immunol. 2012;129[1]:112-8.

54. Huetsch JC, Uman JE, Udris EM, Au DH. Predictors of adherence to inhaled medications among Veterans with COPD 2012 [updated NovPMC3475808]. 2012/07/12: [1506-12]. Available from: https://www.ncbi.nlm.nih.gov/ pubmed/22782274.

55. Lamkin M, Elliott C. Curing the Disobedient Patient: Mediction Adherence Programs as Pharmaceutical Marketing Tools 2014 [Available from: https://digitalcommons. law.utulsa.edu/fac_pub/475.

56. Institute NEH. Thinking outside the pillbox: a systemwide approach to improving patient medication adherence for chronic disease. 2009 [Available from: https://www.nehi.net/writable/publication_files/file/pa issue_brief_final.pdf.

57. Cutler RL, Fernandez-Llimos F, Frommer M, Benrimoj C, Garcia-Cardenas V. Economic impact of medication non-adherence by disease groups: a systematic review. BMJ Open. 2018;8[1]:e016982.

58. Lamkin M, Elliott C. Curing the disobedient patient: medication adherence programs as pharmaceutical marketing tools. J Law Med Ethics. 2014;42[4]:492—500.

59. Senna G, Lombardi C, Canonica GW, Passalacqua G. How adherent to sublingual immunotherapy prescriptions are patients? The manufacturers' viewpoint. J Allergy Clin Immunol. 2010;126[3]:668-9.

60. Rhodes BJ. Patient dropouts before completion of optimal dose, multiple allergen immunotherapy. Ann Allergy Asthma Immunol. 1999;82[3]:281—6.

61.Kiotseridis H, Arvidsson P, Backer V, Braendholt V, Tunsater A. Adherence and quality of life in adults and children during 3-years of SLIT treatment with Grazaxa real life study. NPJ primary care respiratory medicine. 2018;28[1]:4.
62. Hankin CS, Cox L, Lang D, Levin A, Gross G, Eavy G, et al. Allergy immunotherapy among Medicaid-enrolled children with allergic rhinitis: patterns of care, resource use, and costs. J Allergy Clin Immunol. 2008;121[1]: 227-32.

63. Savi E, Peveri S, Senna G, Passalacqua G. Causes of SLIT discontinuation and strategies to improve the adherence: a pragmatic approach. Allergy. 2013;68[9]: 1193-5.

64. Vita D, Caminiti L, Ruggeri P, Pajno GB. Sublingual immunotherapy: adherence based on timing and monitoring control visits. Allergy. 2010;65[5]:668 - 9.

65. Epstein TE, Tankersley MS. Are Allergen Immunotherapy Dose Adjustments Needed for Local Reactions, Peaks of Season, or Gaps in Treatment? J Allergy Clin Immunol Pract. 2017;5[5]:1227-33.

66. Wong PH, Quinn JM, Gomez RA, Webb CN. Systemic reactions to immunotherapy during mountain cedar season: implications for seasonal dose adjustment. $J$ Allergy Clin Immunol Pract. 2017;5[5]:1438—9 e1.

67. Brehler R, Klimek L, Pfaar O, Hauswald B, Worm M, Bieber T. Safety of a rush immunotherapy build-up schedule with depigmented polymerized allergen extracts. Allergy Asthma Proc. 2010;31[3]:e31-8.

68. Cardona R, Lopez E, Beltran J, Sanchez J. Safety of immunotherapy in patients with rhinitis, asthma or atopic dermatitis using an ultra-rush buildup. A retrospective study. Allergol Immunopathol [Madr]. 2014;42[2]:90-5.

69. Casanovas M, Martin R, Jimenez C, Caballero R, Fernandez-Caldas E. Safety of an ultra-rush immunotherapy build-up schedule with therapeutic vaccines containing depigmented and polymerized allergen extracts. Int Arch Allergy Immunol. 2006;139[2]:153-8.

70. Pfaar O, Mosges R, Hormann K, Klimek L. Safety aspects of Cluster immunotherapy with semi-depot allergen extracts in seasonal allergic rhinoconjunctivitis. Eur Arch Otorhinolaryngol. 2010;267[2]:245-50.

71. More DR, Hagan LL. Factors affecting compliance with allergen immunotherapy at a military medical center. Ann Allergy Asthma Immunol. 2002;88[4]:391 - 4 .

72. Carlson GS, Wong PH, White KM, Quinn JM. Evaluation of angiotensin-converting enzyme inhibitor and angiotensin receptor blocker therapy in immunotherapy-associated systemic reactions. J Allergy Clin Immunol Pract. 2017;5[5]:1430-2.

73. Cox L, Nelson H, Lockey R, Calabria C, Chacko T, Finegold I, et al. Allergen immunotherapy: a practice parameter third update. J Allergy Clin Immunol. 2011; 127[1 Suppl]:S1—55. 
74. Lim CE, Sison CP, Ponda P. Comparison of Pediatric and Adult Systemic Reactions to Subcutaneous Immunotherapy. J Allergy Clin Immunol Pract. 2017;5[5]: $1241-7$ e2.

75. Comberiati P, Marseglia GL, Barberi S, Passalacqua G, Peroni DG. Allergen-Specific Immunotherapy for Respiratory Allergy in Children: Unmet Needs and Future Goals. J Allergy Clin Immunol Pract. 2017;5[4]:946-50.

76. Jonasson G, Carlsen KH, Mowinckel P. Asthma drug adherence in a long term clinical trial. Arch Dis Child. 2000;83[4]:330-3.

77. Bousquet J, Hellings PW, Agache I, Bedbrook A, Bachert C, Bergmann KC, et al. ARIA 2016: Care pathways implementing emerging technologies for predictive medicine in rhinitis and asthma across the life cycle. Clin Transl Allergy. 2016;6:47.

78. May JR, Dolen WK. Management of Allergic Rhinitis: A Review for the Community Pharmacist. Clin Ther. 2017;39[12]:2410—9.

79. Jansen A, Andersen KF, Bruning H. Evaluation of a compliance device in a subgroup of adult patients receiving specific immunotherapy with grass allergen tablets [GRAZAX] in a randomized, open-label, controlled study: an a priori subgroup analysis. Clin Ther. 2009; 31[2]:321-7.

80. Rand CS, Wise RA. Measuring adherence to asthma medication regimens. Am J Respir Crit Care Med. 1994; 149[2 Pt 2]:S69-76; discussion S7-8.

81. DiMatteo MR. Variations in patients' adherence to medical recommendations: a quantitative review of 50 years of research. Med Care. 2004;42[3]:200-9.

82. Bender BG. Can health care organizations improve health behavior and treatment adherence? Popul Health Manag. 2014;17[2]:71-8.

83. ACAAI. New toolkit helps patients understand immunotherapy choices 2017 [cited 2018 Aug 19]. Available from: https://college.acaai.org/publications/college-insider/ new-toolkit-helps-patients-understand-immunotherapychoices.

84. Borrelli B, Riekert KA, Weinstein A, Rathier L. Brief motivational interviewing as a clinical strategy to promote asthma medication adherence. J Allergy Clin Immunol. 2007;120[5]:1023-30.

85. Lockey RF, Hankin CS. Health economics of allergenspecific immunotherapy in the United States. J Allergy Clin Immunol. 2011;127[1]:39—43.
86. Hankin CS, Cox L, Bronstone A. The health economics of allergen immunotherapy. Immunology and allergy clinics of North America. 2011;31[2]:325 - 41, x.

87. Hankin CS, Cox L. Allergy immunotherapy: what is the evidence for cost saving? Curr Opin Allergy Clin Immunol. 2014;14[4]:363-70.

88. Canonica GW, Passalacqua G. Disease-modifying effect and economic implications of sublingual immunotherapy. J Allergy Clin Immunol. 2011;127[1]:44-5.

89. Hankin CS, Cox L, Lang D, Bronstone A, Fass P, Leatherman $\mathrm{B}$, et al. Allergen immunotherapy and health care cost benefits for children with allergic rhinitis: a largescale, retrospective, matched cohort study. Ann Allergy Asthma Immunol. 2010;104[1]:79—85.

90. Hankin CS, Cox L, Bronstone A, Wang Z. Allergy immunotherapy: reduced health care costs in adults and children with allergic rhinitis. J Allergy Clin Immunol. 2013;131[4]:1084—91.

91. Allen-Ramey F, Mao J, Blauer-Peterson C, Rock M, Nathan R, Halpern R. Healthcare costs for allergic rhinitis patients on allergy immunotherapy: a retrospective observational study. Curr Med Res Opin. 2017;33[11]: 2039-47.

92. Ariano R, Berto P, Tracci D, Incorvaia C, Frati F. Pharmacoeconomics of allergen immunotherapy compared with symptomatic drug treatment in patients with allergic rhinitis and asthma. Allergy Asthma Proc. 2006;27[2]: 159-63.

93. Petersen KD, Gyrd-Hansen D, Dahl R. Health-economic analyses of subcutaneous specific immunotherapy for grass pollen and mite allergy. Allergol Immunopathol [Madr]. 2005;33[6]:296-302.

94. Pokladnikova J, Krcmova I, Vlcek J. Economic evaluation of sublingual vs subcutaneous allergen immunotherapy. Ann Allergy Asthma Immunol. 2008;100[5]:482-9.

95. Bachert C, Vestenbaek U, Christensen J, Griffiths UK, Poulsen PB. Cost-effectiveness of grass allergen tablet [GRAZAX] for the prevention of seasonal grass pollen induced rhinoconjunctivitis - a Northern European perspective. Clin Exp Allergy. 2007;37[5]:772—9.

96. Schadlich PK, Brecht JG. Economic evaluation of specific immunotherapy versus symptomatic treatment of allergic rhinitis in Germany. Pharmacoeconomics. 2000;17[1]: $37-52$.
Received 03.09.2018

Accepted 14.09.2018 
DOI: 10.22363/2313-0245-2018-22-3-288-301

\title{
АЛЛЕРГЕН-СПЕЦИФИЧЕСКАЯ ИММУНОТЕРАПИЯ: ЭФФЕКТИВНОСТЬ, ПРОДОЛЖИТЕЛЬНОСТЬ, МЕТОДЫ И ФАРМАКОЭКОНОМИКА
}

\author{
Д. Уоллес \\ Современная Школа медицины Юго-Восточного Университета, \\ Форт-Лодердейл, Флорида, США
}

\begin{abstract}
Несмотря на то, что аллерген-специфическая иммунотерапия (АСИТ) более ста лет применяется для лечения аллергического ринита (АР), аллергического конъюнктивита, астмы, атопического дерматита и гиперчувствительности к укусам насекомых, она постепенно достигла всеобщего признания. С опубликованием в 1998 году «Позиционного документа Всемирной организации здравоохранения аллерген-специфической иммунотерапии», в котором обобщены научные данные об эффективности и долгосрочной пользе этого способа терапии, аллерген-специфическая иммунотерапия стала признанной и уважаемой формой лечения. В обзоре обсуждаются следующие темы аллерген-специфической иммунотерапии: причины рекомендации по терапии АСИТ, механизм действия, подкожные и сублингвальные методы применения, продолжительность лечения, соблюдение пациентом назначений врача и экономическая эффективность. Особое внимание уделяется необходимости поддерживать, а не обвинять пациента в несоблюдении назначений врача, поскольку пациент, врач и система здравоохранения в целом должны заботиться о создании среды, в которой пациент будет неукоснительно соблюдать назначения врача. Несоблюдение пациентом назначений врача является следствием большого количества факторов, и врач должен учитывать все факторы с целью обеспечения соблюдения пациентом всех рекомендаций. Желание пациента соблюдать назначения врача необходимо рассматривать в динамике с целью выбора наилучшего времени для начала АСИТ, также необходимо обеспечить наблюдение за пациентом в течение нескольких лет после проведенной АСИТ. Пациент, неукоснительно исполняющий назначения врача в первый год лечения, не сможет быть столь же последовательным на третьем году терапии без дополнительной поддержки. Система здравоохранения и профессиональные организации должны помочь в обучении врачей эффективным и точным способам оценки причин несоблюдения пациентами назначений врача и осуществления мер по оптимизации приверженности пациентов к лечению на продолжении длительного срока. Междисциплинарный подход к решению этой проблемы потребует участия медицинских работников, исследователей, профессиональных организаций, страховых компаний и лиц, определяющих политику в сфере здравоохранения.
\end{abstract}

Ключевые слова: аллерген-специфическая иммунотерапия (АСИТ), подкожный и сублингвальный способы применения, несоблюдение назначений врача, экономическая эффективность

Ответственный за переписку:

Дана Уоллес доцент, Современная Школа медицины Юго-Восточного Университета, Форт-Лодердейл, Голливуд, FL 33019, Флорида, США. E-mail: drdanawallace@gmail.com

Поступила 03.09.2018

Принята 14.09.2018 